\title{
A MAGYAR JÖVŐKUTATÁS FÉL ÉVSZÁZADA A GLOBÁLIS VÁLTOZÁSOK FŐBB IRÁNYAI ÉS A FELZÁRKÓZÁS ESÉLYEI'
}

\author{
HALF A CENTURY OF FUTURES STUDIES IN HUNGARY \\ THE MAIN TRENDS OF GLOBAL CHANGES AND THE CHANCES \\ OF CATCHING UP
}

\author{
Simai Mihály \\ az MTA rendes tagja, research professor emeritus, MTA Közgazdaság- és Regionális Tudományi Kutatóközpont \\ Világgazdasági Intézete \\ mihalysimai@gmail.com
}

\begin{abstract}
ÖSSZEFOGLALÁS
A tanulmány a szervezett intézményesített és tudományos alapokra építő magyar jövőkutatás kialakulásának ötvenedik évfordulója alkalmából választ ad arra, hogy milyen tényezők hatására és milyen feltételrendszerben alakult ki, fejődött és intézményesült a társadalomtudományok e területe az elmúlt évtizedekben, és melyek voltak legfontosabb kutatási eredményei? Egyéni kezdeményezések, társadalmi szükségletek és nemzetközi hatások ösztönözték kibontakozását és fejlődését. Kutatási eredményei között különösen fontosnak bizonyult, hogy megfelelően tudta kezelni az elmúlt évtizedekben azokat a történelmi fordulópontokat, amelyek a nemzetközi rendszerben és Magyarországon is megtörték vagy döntő mértékben módosították a fejlődés trendjeit. Döntő mértékben hatottak a magyar jövőkutatás fejlődésére a tudományok, mindenekelőtt a társadalomtudományok helyzetében, fejlődésében, szerkezetében és szerepében, kutatási módszereiben bekövetkezett változások is. A társadalmi és ökológiai viszonyok közötti szoros kölcsönhatások növekedése és a fenntartható fejlődés különböző dimenzióinak integrálódása nyomán differenciálódtak, bővültek kutatási területei. Különösen nagy jelentőségű fordulatot hozott a magyar jövőkutatásban is az információs forradalom. A magyar jövőkutatás fenntartható fejlődésének alapvető fontosságú biztosítéka elsősorban az elmúlt évtizedekben kialakult, különböző tudományterületekről jött kutatói és oktatói közösség. A tanulmány a jövőkutatás szemszögéből foglalkozik részletesebben a modernizálódás és a felzárkózás problematikájával és feladataival, amelyek az elmúlt évtizedekben a magyar gazdasági és politikai célok között és a tudományos kutatásban is többször kerültek napirendre. Hangsúlyozza, hogy a Magyarország felzárkózásának jövőjével kapcsolatos problémák, feltételek és esélyek vizsgálatánál, amelyet a jövőkutatás egyik központi feladatának kell tekinteni, azoknak az államoknak

${ }^{1}$ A tanulmány Simai Mihály „A magyar jövőkutatás fél évszázada és a globális változások főbb irányai" címủ könyvfejezetének rövidített és átdolgozott változata. In: Nováky E. - S. Gubik A. (szerk.): A múltból átívelö jövő - VIII. Magyar (Jubileumi) Jövőkutatási Konferencia. 50 éves a magyar jövőkutatás, 2018. Budapest, 2018. november 14-25. Konferenciakötet. Györ: Palatia Kiadó és Nyomda, 13-22.
\end{abstract}


és annak a térségnek a jövőjét is kutatni kell, amelyekhez fel akarunk zárkózni. Nem elég természetesen a magyar célokból, elvárásokból és időnkénti illúziókból kiindulni. Felvillantja annak a közegnek a fejlődését és különösen a hosszabb távú fejlődési trendjeit, amelyhez az ország fel szeretne zárkózni, és ennek fényében vizsgálja Magyarország esélyeit.

\begin{abstract}
The occasion of the $50^{\text {th }}$ anniversary of the establishment of organized institutionalized Hungarian futures studies, built on scientific foundations, the paper offers an opportunity for searching a retrospective answer to some of the important questions related to the development of this social sciences branch. Which factors, what national and international conditions comprised the underpinning of Hungarian futures studies, and which were its most important achievements? Individual efforts and initiatives, social needs and international influences stimulated its birth and development. The deep understanding and the proper consideration of historical transformations, inclining or braking trends in Hungary and in the international system had been some of its important achievements. The changes in the role, structure, and methodology of sciences, most of all in social sciences, contributed also to its progress. The increasing interactions between the social and ecological systems and the integration of different aspects of sustainable development resulted in the differentiation and broadening its fields of research. The information revolution has also been a particularly important factor in the studies and research of the future. A fairly important community of researchers and educators from different scientific disciplines comprise the fundamental safeguard for the sustainability and progress of futures studies. The paper is dealing with the problems and tasks of catching up from the perspective of futures studies. During the past decades these two issues have been on the agenda of political goals and scientific research in Hungary. It emphasizes that futures studies, in dealing with the future of catching up, should not study only the Hungarian goals, expectations, and often illusions, but also the future of those states or regions which are the targets of the catching up process. It is analyzing the chances of Hungary from this perspective.
\end{abstract}

Kulcsszavak: jövőkutatás, társadalomtudományok, természettudományok, világgazdaság, Európai Unió, fenntartható fejlődés, Magyarország, modernizáció, felzárkózás

Keywords: futures studies, social sciences, natural sciences, world economy, European Union, sustainable development, Hungary, modernization, catching up

\title{
A TUDOMÁNYOS HÁTTÉR
}

Bármely tudományág múltjának, jelenének és jövőjének elemzésében elengedhetetlen a válasz keresése néhány alapvető kérdésre. Például, hogy mennyire tudta teljesíteni azokat a társadalmi funkciókat, amelyek kialakulását ösztönözték? Milyen új területeken segítette a megismerést? Hozzájárult-e a saját szakterülete tudásbázisának bővítéséhez, kutatási módszereinek fejlesztéséhez? Mennyire fo- 
gadta el vagy fogadta be szerepét és eredményeit a társadalom? Kialakította-e a kutatómunkája müveléséhez és fenntarthatóságához szükséges intézményeket, és biztosítani tudta-e ehhez az anyagi-személyi feltételeket és az utánpótlást? Milyen mértékben és hatékonysággal tudott kapcsolódni más tudományágakhoz, és hasznosítani ezek olyan eredményeit, amelyek hozzájárultak fejlődéséhez? Milyen mértékben kapcsolódott be a szakterületén müködő globális hálózatokba? Előadásomban a válasz keresése során csak felvillantani tudtam a magyar jövökutatás múltjával kapcsolatban néhány témát.

A jövő fejlődésének központi témái: a változások és a kontinuitás a természetben és a társadalmi tevékenységekben egyaránt lényegesek. A jövőkutatás mint tudományterület elsősorban a társadalmi folyamatokkal, változásokkal, ezek tényezőivel és következményeivel foglalkozik, beleértve azonban a társadalom és a természeti feltételek alakulását is. Az elmúlt ötven év során a magyar jövőkutatás fejlődésének globális és hazai tudományos, társadalmi, gazdasági és szervezeti környezetét hatalmas változások jellemezték. Mindenekelőtt szembesülnie kellett az elmúlt évtizedekben azokkal a történelmi fordulópontokkal, amelyek megtörték vagy döntő mértékben módosították a történelmi fejlődés trendjeit. Nemcsak reagálnia kellett a tudományok fejlődésében, szerkezetében és szerepében, továbbá kutatási módszereiben bekövetkezett változásokra, hanem törekednie kellett azok integrálására is. Mindenekelőtt a társadalomtudományok diszciplináris helyzetében és társadalmi szerepében végbement változások hatottak fejlődésére. Jelentős mértékben változtak elméleti alapjai, kutatásának módszerei, és ezek viszonyai a tényekhez és az adatokhoz. A fejlődés szükségleteinek és a tudományos felismerések alakulásának megfelelően a kutatási területei is differenciálódtak, bővültek. Mélyreható változásokhoz vezetett a jövőkutatás viszonylagos helyzetében a társadalmi és ökológiai viszonyok közötti szoros kölcsönhatások nyomán az ökológia szerepének növekedése és a fenntartható fejlődés különböző dimenzióinak integrálódása a társadalom- és természettudományokba. Túl kellett menni az utópiák és disztópiák hatásain, ki kellett lépni az egytényezős ideológiai dogmák gyakran vonzó bűvös köréből. Világosabbá vált az időtényező jellege és fontossága is. Jobban tisztázódott a „gyorsuló idő” képzetének értelmezhetősége és főleg annak megértése, hogy az órák a társadalom életének és fejlödésének különböző területein különböző sebességgel mozognak, és ennek következményei tovább bonyolítják a kölcsönhatásos rendszerek müködését. Ugyancsak jelentős hatással volt a jövőkutatásra a természettudományok helyzetében és a társadalomtudományokhoz való viszonyában végbement átalakulás. Szükült az a szakadék, amelyik a sokak által objektívnek tekintett természettudományok és a szubjektívnek tekintett társadalomtudományok között a megismerés folyamatában fennállt. Werner Heisenberg bizonytalansági elve, a kibernetikus rendszerek komplexitása, a káoszelmélet, amely felismerte a rendet a káoszban, a kvantumfizika új eredményei és az új megközelítések a 
világmindenséggel kapcsolatban viszonylagosabbá tették az évszázadokon keresztül általánosnak hitt, és objektívnak tekintett természeti törvények értékét. Ennek fényében a társadalomtudományok ismeretvilágának forrásai már messze nem voltak annyira értéktelennek, bizonytalannak tekinthetők, mint ahogy ezt korábban állították vagy állítják egyesek ma is.

A jövőkutatásban különösen nagy jelentőségü fordulatot hozott az információs forradalom. A számítógép sokoldalúan használható eszközzé vált. Minden korábbinál több információ áll a kutatók rendelkezésére. Döntő mértékben javult az adatok hozzáférhetősége, tárolásának és kezelésének technikája, és minőségi változások történtek az összehasonlíthatóság tudományosságában is. Ez azonban próbára is teszi a kutatók képességeit. A big data különböző rendszerekből összetett adathalmaza sok információt manipulál. Ezek közé tartoznak például olyan szubjektív alapon kialakított aggregációk, amelyek alapján gyakran idősorok születnek, s a trendfüggőségü jövőkutatókat olyan csapdákba vezetik, amelyekbe esetleg kutatásaik felhasználóit is belerántják. Nagyobb és nehezebb feladattá vált a kutatók számára az, hogy az információkat megfelelően helyezzék el, értékeljék, és képesek legyenek kritikus hasznosításukra. A jövőkutatók többsége ennek nyomán talán körültekintőbbé, tapasztaltabbá is válik.

Döntő fontosságú változás volt a jövőkutatás tudományos, társadalmi és gazdasági jelentőségének és közvetlen hasznának növekvő felismerése. Sokkal világosabbá vált például, hogy a komplexitás és bizonytalanság világában az üzleti élet vagy a kormányok nagyobb távlatokra vonatkozó stratégiai koncepcióinak kimunkálásánál, céljaik realitásának, megvalósíthatóságának értékeléséhez elengedhetetlenül fontosak a különbözö időhorizontokra vonatkozó és alternatív forgatókönyvek (szcenáriók).

Kiemelkedő szerepet játszottak a nemzetközi és magyar jövőkutatás fejlődésében is egyes kiváló tudósok és szakemberek. Felismeréseik és kezdeményezéseik hozzájárultak olyan közös transzdiszciplináris platformok kialakulásához, amelyek a jelenlegi tudományos környezetben különösen elengedhetetlenek.

Sajátos tényező volt a múltban is a politikai rendszer és a jövőkutatás viszonya. Az esetleges tudományos bázisú bírálattól félö és azt nem türő vagy valamilyen fundamentalista irányzatot valló és képviselő politikai rendszerek mindig is ellenezték a jövőkutatást. A legtöbb esetben a politika semleges volt, vagy/és figyelmen kívül hagyta következtetéseit. Kevés országban alakult ki aktív politikai támogatás e tudományterület számára. Magyarországon a jövőkutatás mindhárom politikai megközelítést tapasztalhatta. A hazai társadalmi viszonyok és trendek kutatásának lehetőségei egyenlőtlenek voltak, attól függően, hogy a politikai rendszer mennyire volt akadályozó vagy támogató.

Göröngyös úton haladva ugyan, de a jövőkutatás hazánkban végül is az elszigetelt egyéni tevékenységekből a társadalomtudományok egyik növekvő mértékben elfogadott és bővülő hálózat által támogatott diszciplínájává vált. Egyre nagyobb 
mértékben tudott építeni a tudományterület globális eredményeire, és sikeresen csatlakozott a globális hálózatokhoz. Integrálni tudta olyan jelentős tudományos kutatások eredményeit és tapasztalatait is, mint például a Római Klub jelentései, az OECD „Közös jövő” programja vagy a „Jövő állapota” nevű globális kutatási program. Ez azért volt különösen fontos a számunkra, mert az elmúlt öt évtized hatalmas és a jövő formálódása szempontjából történelmileg szinte példa nélkül álló változások, globális korszakváltások időszaka volt. Folytatódtak a 20. században több fontos területen kibontakozó demográfiai, technikai, társadalmi és politikai, gazdasági, ökológiai és institucionális transzformációk (ilyen volt például a globális problémák megjelenése), másrészt, a század utolsó harmadában, a globális fejlődés szinte minden fontos dimenziójában új szakasz kezdődött.

A magyar jövőkutatás elmúlt öt évtizedének legnagyobb eredménye véleményem szerint az, hogy jól felkészült és különböző tudományterületeken müködő kutatók lelkes hálózata alakult ki, akik nemcsak e tudományterület fennmaradását, hanem a fejlődését is biztosítani tudták.

\section{A 21. SZÁZAD KIHIVÍSAI, A MAGYAR FELZÁRKÓZÁS ESÉLYEI ÉS A JÖVŐKUTATÁS FELADATAI}

A 21. század első két évtizedének globális problémái és trendjei arra utalnak, hogy növekedett a szakadék a problémák kezeléséhez szükségessé vált és a tényleges döntések és a cselekvés között. A szakadék növekedése részben a demográfiai, politikai, gazdasági és társadalmi problémák jellegéből, a hagyományos konfliktusok újjáéledéséből és újak megjelenéséből, a növekvő tudás mellett a tudatlanság új elemeinek megjelenéséből következik. Átalakulóban vannak a politikai és gazdasági hatalmi viszonyok. Ezek már az eddigiekben is aláásták a második világháború után kialakult államközi viszonyok szabályait, és csökkentették a nemzetközi szervezeti együttmüködés hatékonyságát. A globalizáció folyamatában új szakasz bontakozott ki. Ennek egyik különösen lényeges tényezöje a világfejlődésben és mindenekelőtt a magasan fejlett és néhány közepesen fejlett országban kibontakozó új technikai és információs forradalom. Ez nemcsak egy új technikai korszak kezdete, hanem olyan társadalomé is, amelyet joggal neveztek a „tudás társadalmának”, amelyben a technikai és társadalmi változások ötvöződnek.

Buckminster Fuller amerikai kutató sajátos indikátort alakított ki a tudás megkétszereződési idejére vonatkozóan. Eszerint 1900-ig az emberi tudás évszázadonként kétszereződött. A második világháború végéig a megkétszereződési idő huszonöt év volt. Ma például a nanotechnikában ez két év, az egészségügyi technikában tizennyolc hónap. Az emberi tudás átlagosan tizenhárom hónaponként duplázódik. A megkétszereződési mutató népszerü lett az ismeretterjesztő munkákban és a sajtóban, sőt a kutatók körében is, annak ellenére, hogy tudo- 
mányosan nem lehetett bizonyítani, hiszen történelmi és globális adatok erről nem állhattak rendelkezésre. Bizonytalanok azok az adatok is, amelyek az elmúlt néhány évtizedre és a technikai fejlődés különböző területeire vonatkoznak. Összességében azonban vitathatatlan, hogy a felhalmozott tudástömeg hatalmas és kezelhetetlen. Könnyebb és elfogadhatóbb az egyes területeken kialakított és alkalmazott új tudás tömege.

Az új tudás alkalmazása, az ún. „innovatív fejlődés” kibontakoztatása olyan átalakulás, amelyik döntő mértékben függ az adott társadalmak gazdasági képességeitől és készségétöl, intézményeinek nyitottságától és hatékonyságától, alkalmazkodásától. Az innovációs folyamat nem korlátozódik az új technikákra és a gazdaságra. Magában foglalja a hagyományos területeken végbemenő újításokat, a társadalmat és annak intézményrendszerét, sőt az emberek életvitelét is. Ezek közvetlenül is befolyásolhatják egy ország alkalmazkodó képességét, társadalmi kreativitását, a képességet és készséget az innovációk kifejlesztésére és befogadására vagy a kollektív tanulási képességet.

Az érdekviszonyok differenciálódása, a nemzetközi piaci lehetőségekért, a nyersanyagforrásokért, az új technikáért folytatott verseny új szakaszának kibontakozása nyomán a 21. század egyik döntő kérdése nemcsak az lett, hogy folytatódik-e a globális integrálódás, az államok összekapcsolódása az információk, a technika, a töke, az áruk, a szolgáltatások és az emberek nemzetközi áramlásának növekedése, hanem az is, hogy milyen következményekkel járhat az esetleges „deglobalizálódás” vagy az Európai Unió bomlása. Miképpen hatnak a változások a társadalmak átrétegeződésére és a mikroszférára? Folytatódik-e a demokratizálódás, vagy éppen ellenkezőleg, fundamentalista irányzatok, a nacionalizmussal keveredő populizmus, autokrata rendszerek vagy nyílt diktatúrák válnak új, kezelhetetlen problémák és konfliktusok forrásaivá?

Az elmúlt évtizedekben a magyar gazdasági és politikai célok között és a tudományos kutatásban is többször került napirendre két fontos feladat: a modernizálódás és a felzárkózás. A társadalomtudományokban a modernizálódás és a felzárkózás a 20. század második felében főleg a fejlődő országokkal kapcsolatban vált egyik központi fontosságú kérdéssé. A modernizálódást a legtöbb közgazdász az államok homogenizálódási folyamataként fogta fel, amelynek eredményeként társadalmi és gazdasági viszonyaik, termelésük, fogyasztásuk és intézményrendszerük növekvő mértékben válik hasonlóvá, és közeledik egy olyan modellhez, amelyet az adott korban ,példaképnek” tartanak. A felzárkózás értelmezésében a minőségi változások, az államok közötti fejlettségi szakadékok nagysága, csökkenthetősége, az esetleges hanyatlás, az ok és okozati összefüggések és a mennyiségi tényezők szerepeltek. Magyarországon a tudományos életben és a gyakorlatban mindkét feladat megfogalmazása és a folyamataik fogalmának értelmezése a fejlett országok és hazánk közti fejlettségbeli szintkülönbségek csökkentésével kapcsolatos célokból indult ki. 
A Magyarország felzárkózásának jövőjével kapcsolatos problémák, feltételek és esélyek vizsgálatánál, amit a jövőkutatás egyik központi feladatának kell tekinteni, nem elég természetesen a magyar célokból, elvárásokból és időnkénti illúziókból kiindulni. Elengedhetetlenül elemezni kell annak a közegnek a fejlödését és különösen a hosszabb távú fejlődési trendjeit, amelyhez az ország fel szeretne zárkózni, és természetesen a magyar viszonyok, feltételek, követelmények és politikák alakulását.

A felzárkózás céljainak, folyamatának és eredményeinek értelmezése és elemzése az Európai Unióban a jövőkutatás számára különösen tanulságos.

Az európai térség érintett országaira vonatkozóan felzárkózási indexet alakított ki. Az index rögzíti a konvergálódás vagy a különbségek növekedésének szintjét a gazdaság, az élet minősége, a demokrácia és az irányítás területén. A négy témakörre vonatozó indexet harmincöt országra alakították ki, lehetővé téve az öszszehasonlításokat. Nőtt-e az adott országok nemzeti vagyona és gazdasági potenciálja, fejlettebbek és stabilabbak lettek-e gazdaságilag? Jobban élnek-e polgáraik, egészségesebb, képzettebb-e a társadalom, és erősödött-e a társadalmi kohézió, csökkent-e a szegénység? Demokratikusabbak, szabadabbak lettek-e az államok, jobban érvényesülnek-e az emberi jogok? Javult-e a kormányzás minősége, csökkent-e a korrupció és a bünözés? Mindegyik témában sajátos mutatórendszert és súlyozást alakítottak ki (a legmagasabb érték $=100$, a legalacsonyabb $=0)($ How Hard, 2019, 19.). Magyarországra vonatkozóan az indexérték 2018-ban a gazdaságban 44, az élet minőségében 43, a demokrácia tekintetében 36 és összességében 41 volt. A harmincöt ország között a huszonötödik helyen voltunk.

A ma használt mennyiségi mutatók közül a felzárkózás céljait a politikai életben és a közvéleményben szinte kizárólag az egy lakosra számított GDP alapján vizsgálják. Ezt viszonyítják a fejlett államok és különösen az Európai Unió átlagához. A szomszédos Ausztria is kedvelt összehasonlításai alap.

A Magyarországra vonatkozó történelmi trendadatok az egy lakosra számított GDP alapján sem kedvezőek. Hazánk e szerint a 20. század elején már közepesen fejlett ország volt. Ezen a szinten voltunk 1950-ben és 2000-ben is. Az OECD fejlesztési intézete kutatóinak számításai szerint az egy főre számított GDP-mutatók alapján, az 1990-es kereskedelmi árfolyamon számított dollárban mérve, a 21. század elején ott tartottunk, ahol Ausztria 1964-ben. Nem sikerült a felzárkózás a fejlettek közé, pedig voltak modernizációs, felzárkózási törekvések, amelyek azonban, eltérő okokból, de sorra kudarcot vallottak. Ausztriához és Csehországhoz képest valamit behoztunk a monarchia éveiben, de ezt visszavetette az első világháború. Pár lépést tettünk előre a Horthy-rendszerben, 1938-ban „,sikeresen” elértük az 1913-as szintet, az egy före jutó bruttó nemzeti termékben. A második világháború csaknem két évtized fejlődését „,tüntette el”. A szocialista modernizációs kísérlet során is valamivel elöbbre jutottunk, aztán ismét visszaestünk, tehát a felzárkózás szemszögéből ez sem sikerült. Azok a gyakran átmeneti ked- 
vező változások, amelyek például a képzettségi szint, az infrastruktúra, a szociális és egészségügyi viszonyok terén történtek, nem voltak elegendőek a magasabb fejlettségi szintre jutáshoz a 20. század során.

A közepes fejlettség dualitással párosult a gazdaságban és a társadalomban. Kialakultak fejlett gazdasági tevékenységek a termelésben és a szolgáltatásokban, s ezek mellett fennmaradtak igen elmaradott szektorok és tevékenységek is. Nem sikerült megfelelő mértékben kialakítani a felzárkózás egyik alapvető követelményét: a képességet az elmaradott szektorok és térségek felemelésére. Bebizonyosodott, s ez ma is lényeges tanulság, hogy egy kevésbé fejlett országnak sokkal könnyebb felzárkózni a közepes fejlettség szintjére, mint egy közepesen fejlettnek átlépni a fejlett államok csoportjába. A globális versenyben a felzárkózó fejlődők állandó és kemény versenytársak, hiszen gyorsan bővíthetik a jól képzett munkaerő állományát, amire igen jelentős versenyképes gazdasági tevékenységek építhetők. Kína és India például annyi egyetemet végzett munkaerőt bocsát ki ebben az évtizedben, mint az Egyesült Államok és az EU együttvéve. Azzal is tisztában kell lenni azonban, hogy a versenyképesség több szinten értelmezhető: vállalatok, államok vagy nagyobb térségek hasonlíthatók össze. Piaci feltételek mellett egy ország versenyképessége az a szint, amelyen képes arra, hogy szabad és normális feltételek között a nemzetközi piacok ítéletének megfelelö, s azok próbáját kiálló javakat és szolgáltatásokat állítson elö, s ezzel egyidejüleg növelni tudja lakóinak reáljövedelmét, javítani életfeltételeit. Nemzeti szinten a versenyképesség a magasabb termelékenységre és az ország képességére épül, hogy termelését a magas értéket termelő ágazatokba irányítsa, amelyek magas reálbéreket is biztosíthatnak. A versenyképesség javulása azonban nem automatikusan párosul emelkedö életnívóval, növekvő munkalehetöségekkel, és segíti az adott ország fejlődését. Az életfeltételek szempontjából döntő fontosságú egy olyan elosztási rendszer, amely hozzájárul a lakosság helyzetének javulásához is. Mindehhez célorientált dialógusra és együttmüködésre van szükség a politikai és gazdasági élet fö szereplöi között azokban az intézményekben, amelyek a döntések szemszögéből meghatározó fontosságúak.

A 20. században egyébként nem álltunk egyedül abban a tekintetben, hogy a felzárkózási kísérletek nem sikerültek. Csak olyan országok tudtak a fejlettek közé kerülni, vagy azokat jelentősen megközelíteni, amelyekben a kedvezö belső és külső feltételek egybeestek. A belső feltételeket céltudatos és értelmes politika formálta. A kedvező külső feltételek részben igen jelentős anyagi eszközök, részben új technika tömeges beáramlását jelentették, részben biztos külső piacokat, de mindenekelőtt olyan politikai szimpátiát a világgazdaság hatalmasságai részéröl, amely anyagi elönyökre is lefordítható volt, részben például a nemzetközi társaságok közvetítésével. Mi ezekből négy évtizeden keresztül kimaradtunk.

Mennyivel jobbak az esélyek a 21. század következő évtizedeiben? Mennyiben segítette és segítheti a jövőben a felzárkózást részvételünk a legnagyobb és legfej- 
lettebb integrációs szervezetben, az Európai Unióban, amelynek keretében a magyar gazdaság a fejlett piac közvetlen feltételei között müködik? Tapasztalhattuk, hogy új kényszerítő erők, új kötelezettségek, ösztönzők, anyagi, tudományos és technikai források, piaci lehetőségek és új problémák tarkítják az utat, amelyen elöre igyekszünk jutni. A BREXIT is bizonyítja, hogy ez az út sok fejlett állam számára sem bizonyult könnyünek.

Az EU-szerződés - mint említettem - felhatalmazta ugyan a szervezetet, hogy „előmozdítsa” többek közt a gazdasági teljesítmény magas fokú konvergálódását, az életnívó emelését és az élet minőségének javítását, a gazdasági és társadalmi kohéziót, valamint a szolidaritást a tagállamok között, csökkentse a különbségeket a különbözö régiók között a fejlettségi szintben s a kedvezötlen helyzetben lévő térségek elmaradottságát, beleértve a falusi körzeteket is. Ám a felzárkózás az EU keretében nem bizonyult automatikusnak (Rosenau, 1990).

A felzárkózás gyakran említett feladatai között különösen fontos a technikai fejlődés gyorsítása, innovatívabb gazdaság kialakítása, a kutatás, fejlesztés és főleg a diffúziós képességek erősítése révén, a gazdasági szerkezet továbbfejlesztése, beleértve természetesen az agrárszektort. Csökkenteni kell a regionális egyenlötlenségeket egyebek között az infrastruktúra fejlesztése révén. Döntő fontosságú a környezeti feltételek javítása és a fenntartható fejlödés feltételeinek megteremtése. Ezeket a feladatokat a század következő évtizedein is „végigvonuló”, meghatározó fontosságú olyan halmozott globális transzformációk szakaszában kell végrehajtani, mint a globális politikai, katonai és gazdasági hatalmi viszonyok átalakulása, a demográfiai polarizáció és az urbanizációs fordulat, amelyek átrajzolják a föld társadalmi és gazdasági térképét. A jövő formálódásának különösen döntő fontosságú folyamata a tudásalapú társadalom és gazdaság kibontakozása, amelynek komponensei a digitalizáció és a mesterséges intelligencia. A technikai fejlődés és a nemzetközi munkamegosztás átalakulása nyomán új, kemény feltételek bontakoztak ki a globális gazdasági versenyben. Nemcsak a következő évtizedeken, de a 21. századon is messze túlmutatnak a bolygó biológiai létfenntartó képességében kialakult és tovább súlyosbodó problémák. Mindezek nemcsak az olyan országok számára jelentenek példátlanul nehéz politikai, társadalmi és gazdasági környezetet, mint Magyarország, kemény próbára teszik a nemzetközi rendszer politikai és gazdasági hatalmi központjait is.

A jövőkutatás számára ebben e feltételrendszerben nemcsak annak megvilágítása lényeges kérdés, hogy mire képes a feladatok nagyságát és jellegét figyelembe véve a magyar társadalom, hanem az is, hogy mire hajlandó. Figyelembe kell vennie, hogy milyen prioritásokat fogalmaz meg és érvényesít a politika, és mindezekre hogyan reagál a társadalom. A válasz többesélyes. Ezért is fontosak a szcenáriók, a forgatókönyvek. Ezek eredményeivel nemcsak a döntéshozókat kell aktívabban és rendszeresen szembesíteni, hanem a társadalmat is. Ami a társadalmi képességeket és a felkészültséget illeti, egyértelmü, hogy központi fontos- 
ságú feladat ezek javítása. Sem az ún. nemzeti rutin, sem pedig a felkészültség mai szintje nem elég. Magyarország esetében is kísértenek a múlt tehetetlenségi nyomatékai, amikor a feladatokat elszigetelt nemzetgazdasági keretek között szűk csoportérdekek vagy merev, ideológiai megfontolások alapján fogalmazhatták meg. Sem populista jelszavak, sem irreális feltételezések nem ködösíthetik el azt, a jövőkutatás számára is fontos tanulságot, hogy egy ország elszigetelten, „szuverén módon" mindig is képes lehet arra, hogy lejjebb csússzon, felzárkózni általában, de különösen a 21. század feltételei között azonban csak a nemzetközi rendszerben lehet.

\section{IRODALOM}

How Hard Can It Be? (2019): Findings of the European Catch-Up Index 2018. Marin Lessenski Open Society Institute - Sofia, March, http://www.thecatchupindex.eu/TheCatchUpIndex/ Rosenau, J. N. (1990): Turbulence in World Politics. Princeton: Princeton University Press 